\title{
A rising tide lifts all boats:
}

\section{The role of share and category changes in managing organic sales growth}

\section{Authors:}

Arry Tanusondjaja*

The Ehrenberg Bass Institute,

University of South Australia, GPO Box 2471 Adelaide, SA 5001 Australia

arry.tanusondjaja@marketingscience.info

Charles Graham

The Ehrenberg Centre for Research in Marketing,

London South Bank University, 103 Borough Road, London, SE1 OAA, United Kingdom grahamca@1sbu.ac.uk

\section{Steven Dunn}

The Ehrenberg Bass Institute,

University of South Australia, GPO Box 2471 Adelaide, SA 5001 Australia

steven.dunn@,marketingscience.info

Magda Nenycz-Thiel

The Ehrenberg Bass Institute,

University of South Australia, GPO Box 2471 Adelaide, SA 5001 Australia

magda.nenycz-thiel@marketingscience.info

Bruce McColl

The Ehrenberg Bass Institute,

University of South Australia, GPO Box 2471 Adelaide, SA 5001 Australia

bruce.mccoll@marketingscience.info

* Corresponding author 


\title{
A rising tide lifts all boats:
}

\section{The role of share and category changes in managing organic sales growth}

\begin{abstract}
:
The strategic objective of marketing activities is to drive business growth by promoting the firm's products. Beyond merger and acquisition, organic growth can be targeted from two sources: Market Share Gain and Category Growth. Market share is often the focus for corporate objectives and used as a success measure. This research explores the relative impact of these two elements on firm growth across product category and addresses whether market share should be the main focus for all organisations. The study covers 39 consumer packaged goods' categories from the UK and US, across 189 manufacturers over three to five years of data, post-2010. We show that firm growth through market share gain is likely to benefit small firms, and large firms' growth is likely to be driven by category growth. The results provide empirical support in the area of business growth and how marketing plays a crucial role in this pursuit.
\end{abstract}

Keywords: Business growth, market share, category growth. 


\section{A rising tide lifts all boats:}

\section{The role of share and category changes in managing organic sales growth}

\section{Introduction}

The strategic value of marketing to a firm's success is widely acknowledged (Davcik and Sharma, 2016, Kumar et al., 2019) to the extent that the presence of a board-level CMO has been demonstrated to deliver the superior shareholder value that Wall Street demands (Germann et al., 2015). But while leadership sets strategic direction, it is management that executes the firm's marketing capability (Eriksson et al., 2020, Williams, 2007), first identifying where and how to compete (Varadarajan, 2010), then setting goals to manage and deliver growth.

Goal setting in marketing has been occasionally criticised (Binet and Field, 2013, Lodish and Mela, 2007) but scarcely studied (Morgan et al., 2019). While marketers know that growth is an economic imperative (Gordon and Rosenthal, 2003) and a shareholder requirement (Day, 2002), a lack of systematic knowledge might lead to goal-setting that is mechanistic (von Krogh and Raisch, 2007), unrealistic or unambitious. This matters, because growth is a mediator between a firm's marketing capability and its stock market returns (Angulo-Ruiz et al., 2018), so managers need to understand the sources and realistic bounds of growth to specify achievable targets on appropriate metrics.

Business growth is categorised as organic and inorganic. Firms achieve growth inorganically by acquiring businesses or strategic assets, or by merging with another entity (Bahadir et al., 2009), but the focus of this paper is organic growth. It is the wider managerial issue because it concerns the normal business operations of every firm, every day. 
Setting realistic targets for organic growth involves more than a single metric. Revenue and share metrics are not interchangeable, yet they sometimes seem to be regarded as such by managers and researchers. A meta-analysis of determinants of growth (Bahadir et al., 2009) found important inconsistencies in effect size according to whether the dependent variable in the study was market share or revenue. Market share summarises past performance, competitive intensity and market concentration (Farris et al., 2010). Share growth is a nearuniversal ambition, commonly reported to the board and revered on Wall Street. However, sustained increases are rare, and often poorly correlated with changes in revenue because both are cointegrated with category sales (Srinivasan and Bass, 2000). Planning for growth therefore requires consideration of not one, but all three metrics - firm sales revenue, category sales revenue and market share.

Viguerie et al. (2011) reinterpret Ansoff's growth/share matrix to describe the structure of a relationship between the three metrics. They conceptualise market share and category expansion as the two sources of organic revenue growth. Share increases improve the firm's position in current markets, but category expansion contributes revenue growth through portfolio momentum (p.75), building new sales in fast-growth segments or creating and expanding new markets. The relationship is additive not binary; both sources contribute and for management this gives rise to a further consideration - the effect of firm size on achieving the optimum balance between the two.

Bigger firms are expected to own greater slack resource than smaller, but when should they best leverage that capability to target share and when to exploit or increase category growth? Further, is any competitive advantage inherent in firm size likely to mitigate the risk in category expansion strategies? The evidence remains contradictory. Gibrat's Law states that growth rates across firms are independent of absolute size (Gibrat, 1931) and yet, more recent 
studies have found both positive (Bentzen et al., 2012, Morone and Testa, 2008) and negative (e.g., Evans, 1987) correlations, even within industries (Daunfeldt and Elert, 2013). These inconsistencies might occur if revenue growth was driven by differing relative contributions from share increase and category expansion, but beyond case studies, little work has yet systematically examined the proportionate breakdown of a change in revenue that can be attributed to market share change versus category growth or decline.

The aim of this paper is to develop novel empirical generalisations aligning four variables firm size, share growth, category growth, and revenue sales growth. We ask specifically if:

- Firm size is associated with the likelihood of growth or decline in revenue or share

- Firm size influences the relative contributions of market share gain and category growth to changes in revenue

We take firm size as a proxy for strategic capability and change in annual revenue as the strategic outcome to explore the sales performance of 189 manufacturer firms within 39 consumer packaged goods (CPG) categories, across periods ranging from three to five years. We find that revenue growth and share growth are both related to firm size, taking a regular funnel distribution when annual change is plotted against initial share. But there is a different relationship with category performance. For the smallest firms, three quarters of revenue growth can be attributed to share gains. For the largest, the position is almost exactly reversed - sales growth is largely attributed to category growth. Crucially however, a funnel distribution itself implies that annual growth and decline are regularly distributed, therefore firm level growth is largely non-persistent. 
For managers, the findings promote evidence-based rather than habitual goal setting. They contribute to an obvious gap in theory, demonstrating when to prioritise category growth strategies and when to target market share gains.

We proceed as follows. First, we review literature on firm size, market share and category growth as it pertains to persistent sales increase objectives. We then describe the data and the analysis undertaken before presenting the findings. We conclude with a discussion of the results and their implications for theory and for management decision making.

\section{Background}

\section{Goal setting and growth ambitions}

It is taken for granted that firm growth is a measure of success. It has long been held that greater market power and economies of scale deliver and sustain superior profits through advanced marketing management capabilities (Buzzell et al., 1975). Authors since have also linked higher market share to marketing capability. These include a study by Kriz et al. (2014) which identifies its importance in responding and adapting to hyper-competition, while Ailawadi et al. (1999) investigated the effects of "unobserved" capabilities on the ROI of market leaders. The studies conclude that beyond economies of scope and scale, superior profits result from the ability to exploit efficiencies; negotiate better discounts and vertically integrate with suppliers. Since these capabilities are strategic (i.e., they explain sustained superior performance), then growth becomes a virtuous circle (greater firm size brings greater capabilities, greater capabilities lead to increasing growth) in which marketing has been identified as the business function that best increases shareholder value by delivering that growth (Angulo-Ruiz et al., 2018, Germann et al., 2015). 
Yet, astonishingly given this acknowledgement, marketing management has also been roundly criticised for its short-term outlook (Binet and Field, 2013, Lodish and Mela, 2007), for a limited knowledge of econometric modelling (Dekimpe and Hanssens, 2000), for inconsistency in selecting an appropriate dependent variable for growth (Ambler and Kokkinaki, 1997) and for a tendency to determine goals through gut feel alone (von Krogh and Raisch, 2007). Nor is it even clear, despite the relentless focus on growth, that larger firms systematically deliver faster growth at all.

\section{Growth Rate and Firm Size}

Current theories and documented evidence as to how far growth rate is related to firm size remain inconsistent. The well-known benchmark, Gibrat's Law (Gibrat, 1931) states that growth rates across firms are independent of the firms' size, taking a log-normal (and hence, predictable) distribution. If this were so, then setting realistic annual goals for growth would be a simple matter of calculating the size of the steps. A number of authors in the economics domain have investigated this law, but identify a large number of exceptions (Bentzen et al., 2012, Morone and Testa, 2008). One study of particular interest is Hymer and Pashigian (1962), which reports a regular sub-pattern from the analysis of the 1000 largest manufacturing firms in the United States in the decade between 1946 and 1955. They found that average growth rate was independent of the firm's absolute size; but they identified a systematic tendency for the variance to be larger for small firms than for bigger firms - that is, bigger firms may be somewhat more stable than smaller firms.

There may be a number of reasons for this. A limitation of looking at total firm size, whether measured by total revenue, share or even number of employees, is that it does not account for the diversity in the firms' investments across different product categories. Rates of category growth and decline vary (Nenycz-Thiel et al., 2018) and this will impact overall growth at the 
firm level. For instance, two manufacturing goods firms of equivalent size would be expected to have greatly different rates of growth if one predominantly sells goods in growing categories and the other in declining or stationary categories. Recognising and investing early in category growth relies on the ability to exploit "the texture of the market without sacrificing the benefits of scale" (Viguerie et al., 2011, p. 163), whereas strategic capability depends on total firm size.

Further, a firm may have large share in some categories but smaller share in others. If there are advantages in being a 'large firm', these may not necessarily translate to situations where firms have smaller share, although, a superior marketing mix effort for the low share firm might be funded from its scale in another category (Wilkie and Johnson (2017).

Alternatively, some firms may be observed as small at the macro (industry) level because they compete in one category only, despite holding a majority share within that category.

The point is that if relative size influences profitability (Bronnenberg et al., 2011) and management capability (Kriz et al., 2014), then size offers the means, motive and opportunity to set more ambitious growth goals and achieve and sustain those sales increases through tactics that discourage competitor response (Williams, 2007). In order to establish if it is more generally the case that larger firms might consider more ambitious growth objectives, and systematically achieve them, we investigate first if there is evidence for a relationship, positive or negative, between firm size and firm growth at the individual category level, on either a share or a revenue metric, hence our first research question:

\section{RQ1a: Is firm size associated with the likelihood of firm net revenue growth?} RQ1b: Is firm size associated with the likelihood of firm share growth? 
The conception of growth in Viguerie et al. (2011) differs from that in Ansoff. It suggests that revenue increases can be targeted from a combination of its sources, rather than from its discrete quadrants. That view is supported by Edeling and Himme (2018) who explicitly challenge share increase as a sole strategy. Revenue can change with no share movement given a change in total category value - and anticipating and entering fast growth categories may result in share gains and revenue growth from attracting new buyers. The strategic capability to combine strategies may also depend on current firm size. We continue by discussing the nature of the two sources of growth.

Market share is closely watched on Wall Street and in board rooms (Ambler, 2003). Share is an externally focussed metric that summarises performance relative to rivals, so changes are perceived to communicate the effectiveness of past marketing performance. The reason for this is that market share is a zero-sum measure. To the "marketing as warfare" mindset, it gives contextual detail. If a firm has gained share, rivals must have lost out (Franses et al., 2001); if it loses, it is possible to see where share has been redistributed and plan a response.

There is substantial theory to explain how brands can be managed to build consumer-based assets which will protect and develop market share through attitudinal loyalty. Many models of brand equity consider the context of a single brand, although a recent stream of research has advanced theory in developing a model of value attribution that explicitly considers the relative competitive context - customer-based brand value (CBBV) (e.g., Winzar et al., 2018, Gupta et al., 2020). Widely accepted in practice, these theories are typically derived from survey responses or models that capture attitude and intention in cross-section. They may or may not reflect the actual size of the brand or firm in the market because in established categories attitudes are transient and loyalty divided (Ambler, 2003). The behavioural 
evidence in CPG categories suggests that shares are volatile in the short term, but that persistent share gains (i.e., over five or six years) occur in only around two in ten cases (Graham, 2009). Market shares are held in a competitive equilibrium because individual consumer buying propensities remain largely fixed over a repertoire of brands, and switching divides a fixed category demand over a fixed number of choices (Trinh, 2014).

Figure 1. Quarterly market shares of two leading detergent brands over five years

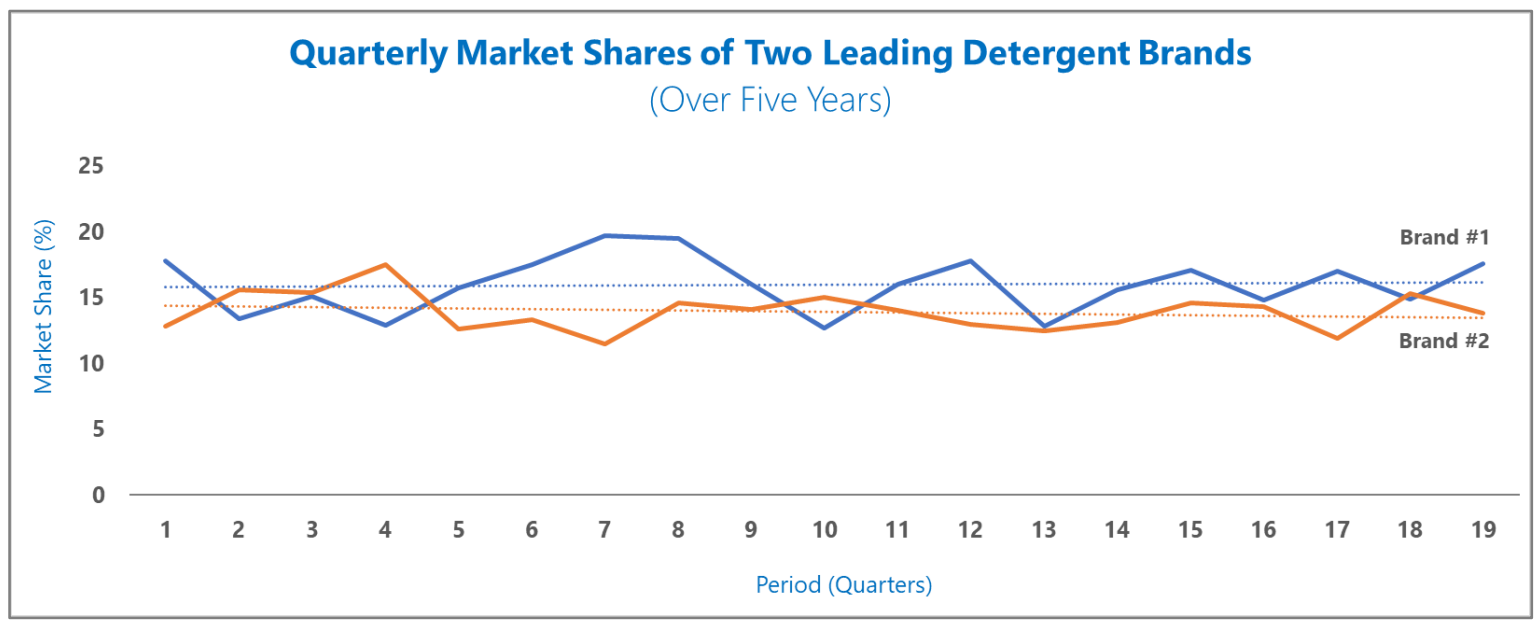

Data source: Kantar Worldpanel. 15,000 UK households, 2009 to 2014

Figure 1 reports a typical result, showing quarterly market shares for two brands of detergent over five years. The pattern is highly dynamic, yet the movements are merely off-setting. Losses for A are gains for B, and vice versa, so both brands have a long-run mean that trends by less than one share point over the observations. Intense rivalry ensures that any advantage is quickly competed away.

It still remains the case that annual share growth objectives are almost universally set, and almost universally rewarded. But if persistent rather than temporary share growth is ever achieved in equilibrium markets, it is primarily achieved by attracting the purchasing of more of the customers of all other firms (Dawes, 2016). Scale and scope are needed to move the whole market in order to shift the penetration of a single brand permanently in this way. 


\section{Category Growth and Firm Size}

It is the case, however, that category sales are less stable than brand shares. Dekimpe and Hanssens (1995) found that sales series are non-stationary in around two-thirds of cases, but share series remain stationary in $78 \%$ of cases. The effect of every share point increasing in value leads to the situation alluded to in our title, where a rising tide lifts all boats. Category growth benefits all participants, but with the highest absolute rewards gained by the market leader.

Evidence for the success of marketing tactics to achieve category growth is mixed. Categories expand only when they attract new consumers, when existing consumers can be encouraged to increase their usage, or to pay more for the same volume - or some combination (NenyczThiel et al., 2018, Dawes et al., 2019). For example, it was long thought that price promotion could introduce new buyers to an existing firm, yet even though it is typically the largest investment in brand support, it has been shown to have virtually no effect on category expansion (Nijs et al., 2001).

Increasing physical distribution may have the effect of increasing both purchase frequency and penetration in certain categories. Several studies report the incremental sales can be achieved through omni-channel marketing strategies (e.g., Ailawadi and Farris, 2017, Pauwels and Neslin, 2015, Verhoef et al., 2015) but again, it remains unclear if these are category sales increases or simply an off-setting advantage (i.e. market share growth) against less available rivals.

New tangible product benefits can compel some consumers to pay more sometimes (Dawes et al., 2019), but without necessarily increasing penetration or usage. Category value may 
then increase quickly when a successful innovation for one brand or firm is imitated by rivals (including Private Label), creating a new market segment.

As with market share, if the size of a firm indicates strategic capability, then market power may well have a bearing on the likelihood of achieving category expansion. It is commonly proposed that category leaders in equilibrium markets can expand total category sales by finding new buyers or new product uses, while (at least) maintaining share. But the implication is that it may require the financial leverage of a large firm to disrupt the established buying propensities of an entire market (Leeflang et al. (2017) and that the nature of radical innovation requires scale for its successful diffusion (e.g., Andreassen et al., 2017). Equally, others have argued that smaller firms, which are particularly driven to innovationbased marketing strategies, benefit from market focused learning (Weerawardena et al., 2006) and are thus relatively better placed to disrupt and expand categories. But in either case, successful innovation must contribute revenue growth through category and share growth.

There are however few benchmarks available to managers about the relative contributions that share and category change might be expected to make to revenue growth or decline. Further, any evidence of a relationship between firm size and any changes is contradictory. To provide those benchmarks, we therefore, examine the relationship between firm size and relative change in the share and/or category value. Hence, we ask:

RQ2a: Does firm size influence the relative contribution of share gains versus category growth in producing firm net revenue growth?

RQ2b: How does the finding for RQ2a vary across growing, declining, and stable firms? 


\section{Method}

The research adopts the principle that empirical generalisations are the building blocks of theory, in addressing the research questions. An empirical generalisation is defined as a relationship between two or more variables that have been observed across a range of conditions (Uncles and Wright, 2004). This approach therefore starts with data rather than theory. It requires the observation of patterns and regularities that are supported across multiple sets of data (MSoD). Theory is developed later to explain the empirical regularities and their boundary conditions, rather than embarking on research to test an isolated theory in a single set of data (SSoD). This approach to marketing science was promoted strongly by Andrew Ehrenberg, who emphasised that it results in more academically robust and practically useful knowledge that is more representative of 'real world' conditions (Ehrenberg, 1994).

Another important benefit of applying a MSoD approach is that inferential statistics are not needed to provide robustness to the results (Kennedy et al., 2014, Ehrenberg and Bound, 1993). Ehrenberg and Bound (1993) claim that if the findings are successfully replicated each time on different data populations, then there is no need to verify whether an inference or generalisation can be made about the current fit of the sample to the population.

Consequently, this research is based on an analysis of the sales performance of 189 manufacturer firms in 39 UK and US CPG product categories, from retail scanner data sets ranging between three and five years, post-2010. Retail scanner databases consist of SKU sales transactions, typically collected on a weekly basis at the individual store-level. Firms such as Kantar, IRI, and Nielsen are the main suppliers of retail scanner data, which covers a large proportion of total retail sales occurring across different regions and outlet types (e.g., grocery, convenience, mass merchandiser, and club stores). Retail scanner data has long been 
a common source for studies of sales performance in consumer goods categories, notably when investigating marketing-mix effects (e.g., Ataman et al., 2010, Wilbur and Farris, 2014, van Heerde et al., 2000) and long-run changes to market structure (Dekimpe et al., 1998).

The retail scanner data sets used in this research were developed by Nielsen and obtained from our industry research partners. The sales in our data sets were aggregated to the annual brand-level across the total market. Except for Figure 1, all of the tables and subsequent figures are derived from Nielsen retail scanner data. The details of the product categories and the number of firms in each is included in Appendix A. Manufacturers are considered distinct within each product category due to varying firm performance in terms of market share across different categories. This is also in line with business practice, where different divisions or business units may manage the brands in each product category. We use value market share as a proxy for initial manufacturer size, the proportion of total market revenue apportioned to the firm in the observation period.

To avoid survival bias (i.e. excluding any firms that ceased to trade during the analysis period), observations were converted to 488 year-on-year individual cases. This had the additional benefit that data sets of varying length (three to five years) could then provide multiple observations per firm and be aggregated into a large sample. Our interest is in estimating associations between firm Net Revenue Growth (NG) and category and market share dynamics. Net revenue growth is defined as the relative change in total firm revenue sales, which takes into account both elements of growth (Share Gains and Category Growth) - compared to the absolute amount in the previous year.

In line with the approach outlined by Viguerie et al. (2011), we decoupled Share Gain (SG) and Category Growth (CG) from the year-on-year firm Net Revenue Growth (NG) using the 
formula below. Net Revenue Growth rate is simply the revenue growth for the firm that intrinsically contains its share gains and the growth in the whole category.

For Firm $A$ in Year $Y$, the two growth elements are calculated using the following formulae:

SG.A = ((MS.Ay $x$ Revenue.A $(\mathrm{Y}-1)) /$ Revenue.A $\left._{(\mathrm{Y}-1)}\right)-1$

$\rightarrow$ The growth rate brought by capturing a bigger (or smaller) portion of the total market revenue from the competitors.

CG $=($ Total Market Revenue $/$ Total Market Revenue $(\mathrm{Y}-1))-1$

$\rightarrow$ The growth rate brought by the overall growth (or decline) to the total market.

NG.A $=$ SG.A $+\mathbf{C G}$ or alternatively $\mathbf{N G . A}=\left(\right.$ Revenue.A $_{\mathbf{Y}} /$ Revenue.A $\left._{(\mathbf{Y}-1)}\right)-\mathbf{1}$

$\rightarrow$ The overall revenue growth taking into account any share gains and the category growth.

To compare how each element contributes to the Net Revenue Growth, the following apportioning calculation is adopted, by taking the absolute value of the growth to cater for a negative value in one or both elements:

SG.A $\%=\mid$ SG.A $|/|$ NG.A $\mid$

$\rightarrow$ The portion of the Net Revenue Growth rate allocated to Share Gains.

CG.A\% $=\mid$ CG.A $|/|$ NG.A $\mid$

$\rightarrow$ The portion of the Net Revenue Growth rate allocated to Category Growth.

Having extracted the relevant values, the data were summarised in simple tabulations and graphs to expose the regularities and associations needed to address the four research questions. 


\section{Results}

Net Revenue Growth Rate and Firm Size

The analysis of the individual firms' year-on-year data reveals the diminishing possibility of large annual growth or decline in revenue as it increases in size (as measured by the initial market share). Table 1 shows the range of firm sizes, grouped into deciles according to the initial market share, along with the growth rates experienced by the firms in each decile. The smallest firms (the bottom decile) are those that experience the largest swings in Net Revenue Growth (Mean: 2.3\%; SD: 17\%; Median: $-0.2 \%$; Range: $-42 \%$ to 102\%; $n=245$ ). Their low initial market share enabled them to experience a wider range of year-to-year change compared to the largest firms in the category (Mean: 1.6\%; SD: 4.8\%; Median: $1.8 \%$; Range: $-13 \%$ to $11 \% ; \mathrm{n}=67)$ - as shown in Table 1 . The largest firms are those with an initial market share of $40 \%$ or more in the product category.

Table 1: Average Net Revenue Growth by Firm Size (Market Share)

\begin{tabular}{l|c|c|c}
\hline \multirow{2}{*}{ Market Share } & \multirow{2}{*}{$\mathbf{n}$} & \multicolumn{2}{|c}{ Net Revenue Growth (\%) } \\
\cline { 3 - 4 } & & Average & SD \\
\hline$<10 \%$ & 245 & 2.3 & 17.3 \\
$10 \%-19 \%$ & 92 & -0.6 & 9.5 \\
$20 \%-29 \%$ & 52 & 1.6 & 6.6 \\
$30 \%-39 \%$ & 32 & 1.0 & 5.1 \\
$40 \%+$ & 67 & 1.6 & 4.8 \\
\hline All Firms & $\mathbf{4 8 8}$ & $\mathbf{1 . 5}$ & $\mathbf{1 3 . 3}$ \\
\hline
\end{tabular}

When the net revenue growth rates are plotted against the initial market share (Figure 2), they take a funnel-shaped distribution, with higher variance for small firms that taper to a narrow band of growth for bigger firms. Large growth (and losses) are more likely to occur for smaller firms compared to large firms (RQ1a), as shown in Figure 2. 
Figure 2. Year-on-Year Firm Net Revenue Growth and Decline, by Firm Size

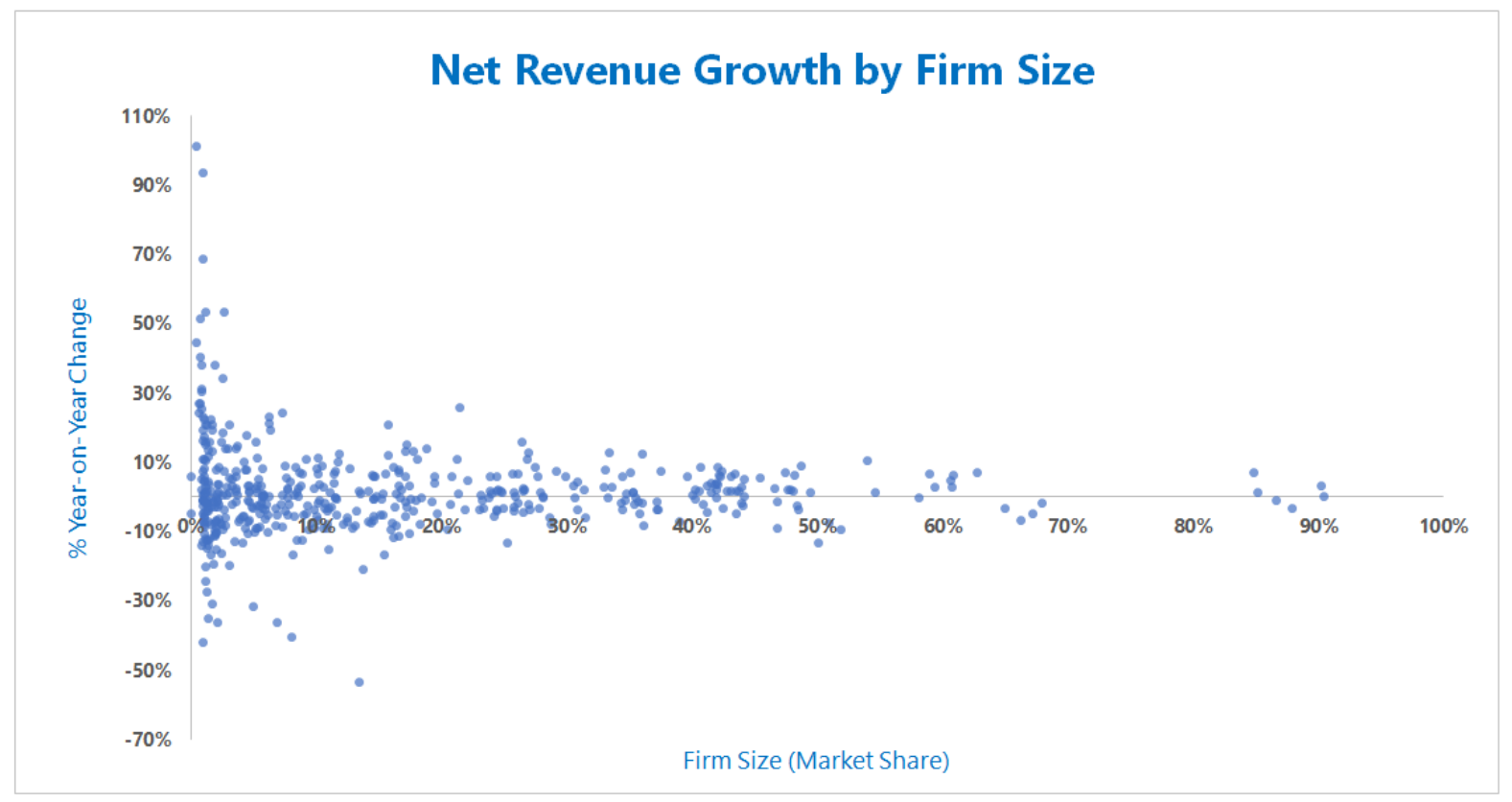

Share Gains vs Category Growth by Firm Size

Next, the analysis decomposes the net annual revenue growth and decline of the firms to understand the relative contribution from changes in market shares (share gains) and changes in the size of the whole categories (category growth). Table 2 reports the incidence of category growth and share gains observed across the 39 product categories. Overall, average year-on-year growth rates were relatively close for category growth and share gains $(1.1 \%$ and $0.4 \%$, respectively). However, the two sources of growth differed greatly in the range of the results. All category growth was within the bounds of $-9.1 \%$ to $10.2 \%$ (SD: $3.6 \%$ ), whereas share gains ranged from $-56 \%$ to $103 \%$ (SD: 12.7 ). This indicates the possibility for share gains to have a more sizeable impact on net revenue growth. 
Table 2: Average Share and Category Growth by Firm Size (Market Share)

\begin{tabular}{|c|c|c|c|c|c|c|}
\hline \multirow{2}{*}{ Growth/Decline from: } & \multirow{2}{*}{$\mathbf{n}$} & \multirow{2}{*}{ Average } & \multirow{2}{*}{ SD } & \multicolumn{3}{|c|}{ Year-on-Year Change (\%) } \\
\hline & & & & Median & Min & Max \\
\hline \multicolumn{7}{|l|}{ Category Growth: } \\
\hline Total & 101 & 1.1 & 3.6 & 1.2 & -9.1 & 10.2 \\
\hline \multicolumn{7}{|l|}{ Share Gains: } \\
\hline$<10 \%$ Share & 245 & 1.3 & 16.7 & -1.0 & -40.3 & 102.5 \\
\hline $10 \%-19 \%$ Share & 92 & -1.4 & 8.9 & -1.8 & -56.3 & 18.4 \\
\hline $20 \%-29 \%$ Share & 52 & 0.1 & 5.2 & -0.2 & -13.4 & 14.2 \\
\hline $30 \%-39 \%$ Share & 32 & -0.6 & 4.9 & -1.2 & -12.5 & 11.8 \\
\hline $40 \%+$ Share & 67 & 0.4 & 2.8 & 0.4 & -5.9 & 7.3 \\
\hline Total & 488 & 0.4 & 12.7 & -0.7 & -56.3 & 102.5 \\
\hline
\end{tabular}

While category growth has the potential for a uniform impact across all competing firms, individual rivals of different size may at the same time differ in their capacity to capture or lose share. As with net revenue growth, the distribution of market share changes takes a funnel-shape when year-to-year change is plotted against initial market shares (Figure 3). As also shown in Table 2, the largest swings in market share are more prevalent among the smallest firms. For the firms with an initial share of $40 \%$ or greater, market shares are far more stable (Mean: 0.4\%; SD: 2.8\%; Median: 0.4\%; Range: $-5.9 \%$ to $7.3 \%$; $n=67$ ). The assumption of market share stationarity broadly holds for these largest firms, implying lower likelihood of net revenue growth through share gains $(R Q 1 b)$. 
Figure 3. Year-on-Year Firm Market Share Changes, by Firm Size

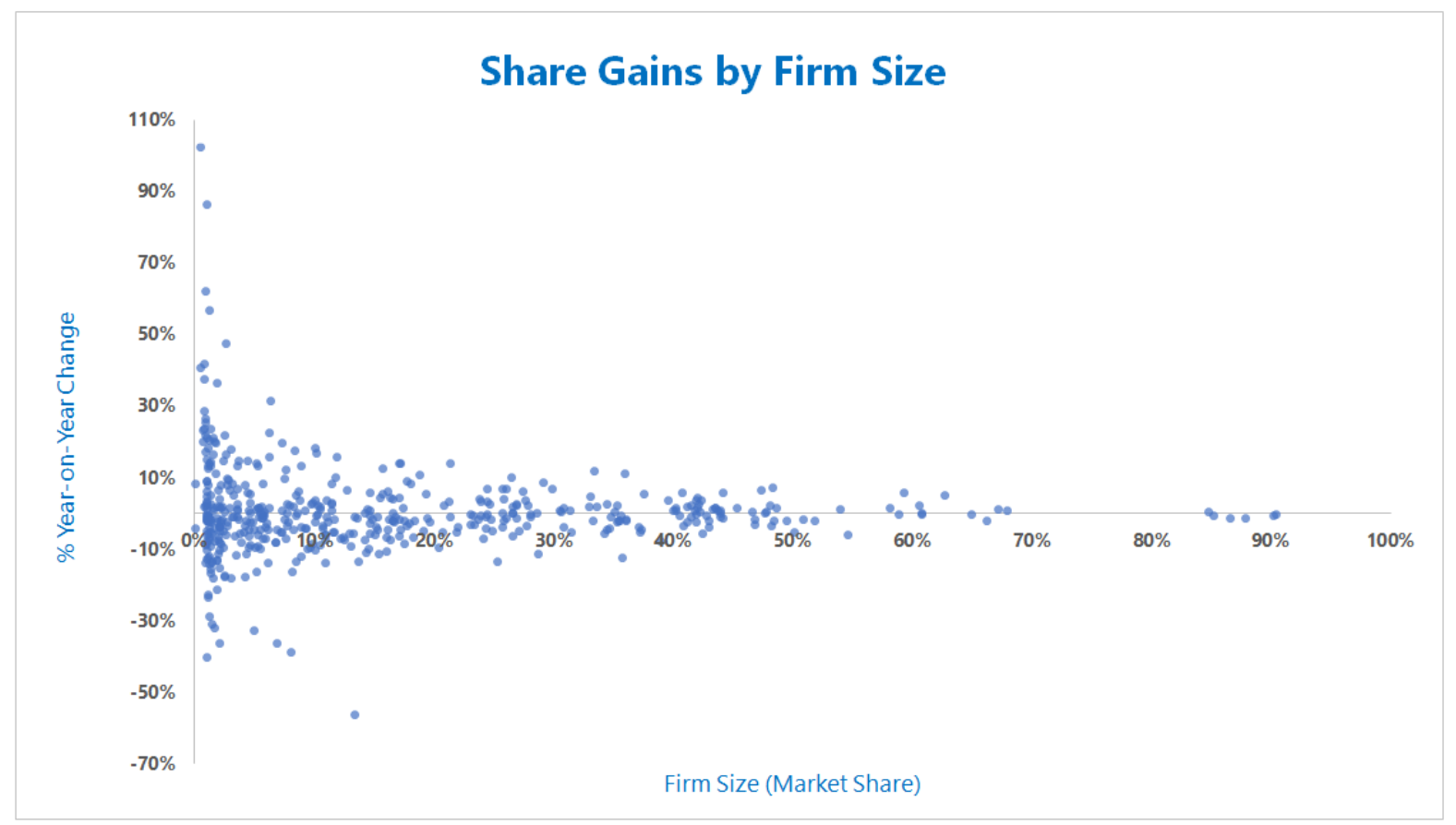

As firms increase in size, there is a greater reliance on category growth for firms to achieve net revenue growth. This pattern is apparent when we calculate the percentage of net growth or decline that can be apportioned to category growth as opposed to the share growth, by firm size, as shown in Table $3(R Q 2 a)$. On average, category growth accounts for just $27 \%$ of net revenue growth and decline among the smaller firms $(<10 \%$ share $)$, but this figure increases to $60 \%$ among the larger firms $(40 \%+$ share $)$. Overall, firm growth and decline has stronger correlation with share gains $(\mathrm{r}=0.97)$ than category growth $(\mathrm{r}=0.25)$. This pattern broadly holds across the firm sizes, until they reach $40 \%$ or more, and there is a greater association with category growth $(r=0.82)$ then share gains $(r=0.51)$. 
Table 3: Contribution of category growth and share gains to net revenue growth

\begin{tabular}{l|c|cc|cc}
\hline \multirow{2}{*}{ Market Share } & \multirow{2}{*}{$\mathbf{n}$} & \multicolumn{2}{c|}{$\begin{array}{c}\text { \% Avg. of Net Revenue } \\
\text { Growth/Decline attributed to }\end{array}$} & \multicolumn{2}{c}{$\begin{array}{c}\text { Net Revenue Growth/Decline } \\
\text { correlation with: }\end{array}$} \\
\cline { 2 - 6 } & & Category Growth & Share Gains & Category Growth & Share Gains \\
\hline$<10 \%$ & 245 & 27 & 73 & 0.21 & 0.98 \\
$10 \%-19 \%$ & 92 & 36 & 64 & 0.27 & 0.94 \\
$20 \%-29 \%$ & 52 & 40 & 60 & 0.58 & 0.87 \\
$30 \%-39 \%$ & 32 & 37 & 63 & 0.27 & 0.89 \\
$40 \%+$ & 67 & 60 & 40 & 0.82 & 0.51 \\
\hline All Firms & $\mathbf{4 8 8}$ & $\mathbf{3 5}$ & $\mathbf{6 5}$ & $\mathbf{0 . 2 5}$ & $\mathbf{0 . 9 7}$ \\
\hline
\end{tabular}

The differing contributions of category and market share changes by firm size can also be seen in Table 4, where the firms are split into those that were growing $(>2 \%)$, declining $(<2 \%)$ or stable ( -2 to $2 \%)$. Among the smaller firms $(<10 \%$ share), those that were growing and declining differed far more on their rates of change in market shares (14.8\% vs $-10.5 \%)$ than their category growth $(1.7 \%$ vs $0.5 \%)$. This difference reverses as the firms increase in size. The largest firms $(40 \%+)$ that grew versus declined differed more in their rates of category growth and decline $(3.5 \%$ vs $-4.5 \%)$ than any market share changes $(1.7 \%$ vs $1.1 \%$ ). Overall, these results identify that the relative contributions of category growth and share gains to net revenue growth vary by firm size, with category growth having a greater impact on larger firms $(R Q 2 b)$. 
Table 4: Year-to-year growth rates across growing, declining, and stable firms

\begin{tabular}{|c|c|c|c|c|}
\hline \multirow{2}{*}{$\begin{array}{c}\text { Firms } \\
\text { (By Size \& Net Revenue Growth) }\end{array}$} & \multirow[b]{2}{*}{$\mathbf{n}$} & \multicolumn{3}{|c|}{ Average Year-on-Year Change (\%) } \\
\hline & & Category Growth & Share Gains & $\begin{array}{l}\text { Net Revenue } \\
\text { Growth }\end{array}$ \\
\hline \multicolumn{5}{|l|}{ Market Share $<10 \%$} \\
\hline Growing $(>2 \%)$ & 96 & 1.7 & 14.8 & 16.7 \\
\hline Stable (-2 to $2 \%)$ & 47 & 0.7 & -0.7 & 0.0 \\
\hline Declining $(<2 \%)$ & 102 & 0.5 & -10.5 & -10.1 \\
\hline \multicolumn{5}{|l|}{ Market Share 10-19\% } \\
\hline Growing $(>2 \%)$ & 32 & 2.3 & 6.1 & 8.4 \\
\hline Stable (-2 to $2 \%)$ & 22 & 1.3 & -1.3 & 0.0 \\
\hline Declining $(<2 \%)$ & 38 & -0.6 & -7.8 & -8.5 \\
\hline \multicolumn{5}{|l|}{ Market Share 20-29\% } \\
\hline Growing $(>2 \%)$ & 18 & 3.5 & 4.6 & 8.3 \\
\hline Stable $(-2$ to $2 \%)$ & 18 & 0.5 & 0.1 & 0.6 \\
\hline Declining $(<2 \%)$ & 16 & 0.3 & -5.1 & -4.9 \\
\hline \multicolumn{5}{|l|}{ Market Share 30-39\% } \\
\hline Growing $(>2 \%)$ & 12 & 2.3 & 4.0 & 6.4 \\
\hline Stable (-2 to $2 \%)$ & 12 & 1.7 & -1.9 & -0.3 \\
\hline Declining $(<2 \%)$ & 8 & 0.7 & -5.4 & -4.9 \\
\hline \multicolumn{5}{|l|}{ Market Share 40\%+ } \\
\hline Growing (>2\%) & 33 & 3.5 & 1.7 & 5.3 \\
\hline Stable (-2 to $2 \%)$ & 20 & 1.3 & -0.8 & 0.4 \\
\hline Declining $(<2 \%)$ & 14 & -4.3 & -1.1 & -5.4 \\
\hline
\end{tabular}

\section{Conclusion and Implications for Theory and Practice}

The aim of this study was to establish an evidence-based understanding of the elements of firm revenue growth, its constituents (share and category growth), and variations across firm sizes using market share as the proxy. We report four novel contributions from the study, with clear implications for those who set growth objectives; an overarching conclusion is that managers are strongly advised to avoid setting single-metric goals for organic growth. We summarise the findings, discuss their implications, then turn to the limitations of the study and avenues for future research. 


\section{There is lower possibility for large revenue growth or decline for bigger firms.}

First, we show the extent to which smaller firms can expect larger growth rates, but also larger declines, while for larger firms the expectation should be for stability or very modest growth. We also report a similar phenomenon to that documented by Hymer and Pashigian (1962) of a systematic tendency for the variance to be larger for small firms than it is for bigger firms. These findings add empirical support for businesses when setting attainable and realistic goals for growth in the market, depending on their size. Our study also shows that there is a complex relationship between firm size and the year-on-year growth rate, related to category dynamics. This means that when setting revenue growth targets consideration must be given to the actions of three variables; share growth, category growth and firm size. A single market share objective combined with a mechanical year-on-year percentage increase is unlikely to be adequate.

\section{There is lower possibility for market share growth or decline for bigger firms.}

Regardless of how the category is performing, large firms are unlikely to gain further growth by 'stealing' from other competitors in the market (i.e., gaining bigger share). There is an impetus for big firms $(40 \%+$ share $)$ in the market to otherwise set their objectives to grow the whole category, as this would in turn benefit all firms in the market. Share gains are also possible, but they are often enjoyed by more players participating in that category expansion - the rising tides that lift all boats. For big firms, strategies to increase the likelihood of revenue growth - either by attracting more buyers in, and/or extracting higher value from their consumption, depending on the category development stage (Dawes et al., 2019, Nenycz-Thiel et al., 2018) - are in line with this finding. At a wider firm-level, the importance of category growth should also guide portfolio decisions taken by large firms when selecting categories to invest in for growth. 
3. On average, 35\% of net revenue growth or decline is attributable to category growth.

When setting growth objectives, firms need to take into account the category dynamics because, on average, $35 \%$ of the year-on-year growth and decline of the firm depends on how well the category is performing. However, for big firms (with $40 \%++$ market share), the level of contribution is $60 \%$, which emphasises the importance of category growth for the firm net revenue growth.

4. More of the growth for bigger firms is generated from category growth than market share

The results show that among the smaller firms $(<10 \%$ share $)$, rates of change in market share contributed far more to revenue changes than any movement in category value. For the largest firms $(40 \%++)$, in line with the previous point, the relationship is reversed - so firms that grow or decline are more likely to be affected by the category growth or downturn than by market share movement.

\section{Practical implications of the Share Metric}

The funnel distribution implies that there is little sustained growth over several years. For managers, it may be tempting to interpret a substantial but temporary sales spike in one year as a persistent share increase, but this signal to noise ratio is one of a number of complications identified by Farris et al. (2010) about the share metric. A short-term spike (noise) communicates the effectiveness of a promotion or other intervention, but a longerterm, no-trend view (the signal) does not easily reveal that swings in share bring back buyers from competing brands, and therefore contribute to cumulative performance. Managerial 
insight benefits from both views, but there may be great pressure from financial markets and elsewhere to emphasise the short term, and to present the noise as the signal.

When setting market share goals, market definition may also be selective - there is often a choice of pie to report on and it is sometimes attractive for management to report segment leadership. Small, often innovative firms report high market share in consumer and trade communications on this basis because it implies strong demand to potential customers. On closer inspection however, it might only risk revealing a lack of competition in a small competitive space.

The role of category dynamics and investigation into category growth strategies

Category dynamics are critical in the interpretation as well as the setting of market share metrics. Claiming a gain in market share as a success or considering decline as a failure is contingent on the total category sales. Merely maintaining sales value in a growing category is reflected in declining share. Conversely, brand share growth in declining markets is misleading because it masks the reducing market size and may only reflect stable sales performance. Furthermore, the investment necessary to secure and grow brand share in a shrinking market could be better directed to developing a position in an emerging part of a category. This is well highlighted by the case of Nokia, the dominant brand in a declining mobile phone business. In 2007, Nokia's market share was $49 \%$ but it plummeted to $3 \%$ within six years (Lee, 2013), as the mobile phone market morphed into a smart phone market, where Nokia (famously a brand that had reinvented itself several times over) had no competing product. 
In conclusion, this research highlights the significance of understanding the sources of revenue growth for a firm - and the importance of category growth, especially for the bigger firms. Accordingly, our study documents the limitations of focusing on market share as a focal metric when goal-setting or assessing the performance of a firm without considering the performance of the category as well as other factors such as firm size.

Avenues for future research

One of the major implications from this research is that category expansion will be the primary source of growth for large firms. As such, these firms need objectives and strategies for growing their categories. Given a lack of category growth studies in the marketing literature to date, this requires new research to understand the incidence, norms and the antecedents of category growth.

To set realistic category expansion objectives, further research is needed to determine the likely incidence of category expansion and contraction over the short, medium and long-term. Further strategic guidance can be gained from an empirical analysis of the extent to which category growth is driven by attracting more users, activating further usage and driving premiumisation along with the conditions under which these strategies can be expected to best succeed (Dawes et al., 2019, Nenycz-Thiel et al., 2018). Future research should also aim to provide a category growth lens to a better understanding of the potential in marketing activities. In stationary categories, investments, such as price promotion and advertising may achieve share gains (at least in the short-term) but have negligible effects on expanding the entire category. In expanding categories, elasticities may be both greater and more persistent. 
Finally, in this study we considered growth outcomes rather than their determinants. There are many factors that moderate a firm's growth rate - such as market concentration, entry barriers (Lee, 2009), the age of the firm (Evans, 1987, Heshmati, 2001, Morone and Testa, 2008), the strategy, organisation, and the characteristics of the firm's owners (Fazzari et al., 1988, Lumpkin and Dess, 1996, Freel and Robson, 2004), and other environmental factors (e.g., financial climate) (Gupta et al., 2013). Each of the published studies to date focuses only on a selection of variables and while associated with a high level of difficulty, future research should focus on understanding how the variables interact to give a full picture on the moderators of firm's growth rates. 


\section{References}

AILAWADI, K. L. \& FARRIS, P. W. 2017. Managing Multi-and Omni-Channel Distribution: Metrics and Research Directions. Journal of Retailing, 93, 120-135. AILAWADI, K. L., FARRIS, P. W. \& PARRY, M. E. 1999. Market share and ROI: Observing the effect of unobserved variables. International Journal of Research in Marketing, 16, 17-33.

AMBLER, T. 2003. Marketing and the Bottom Line, London, United Kingdom, Pearson Publication.

AMBLER, T. \& KOKKINAKI, F. 1997. Measures of marketing success. Journal of Marketing Management, 13, 665-678.

ANDREASSEN, T. W., LERVIK-OLSEN, L. \& KURTMOLLAIEV, S. 2017. Innovation economics. In: ANDREASSEN, T. W., HILLESTAD, T. \& LÜDERS, M. (eds.) Innovating for Trust. Cheltenham, United Kingdom: Edward Elgar Publishing.

ANGULO-RUIZ, F., DONTHU, N., PRIOR, D. \& RIALP, J. 2018. How does marketing capability impact abnormal stock returns? The mediating role of growth. Journal of Business Research, 82, 19-30.

ATAMAN, M. B., VAN HEERDE, H. J. \& MELA, C. F. 2010. The long-term effect of marketing strategy on brand sales. Journal of Marketing Research, 47, 866-882.

BAHADIR, S. C., BHARADWAJ, S. \& PARZEN, M. 2009. A meta-analysis of the determinants of organic sales growth. International Journal of Research in Marketing, $26,263-275$.

BENTZEN, J., MADSEN, E. S. \& SMITH, V. 2012. Do firms' growth rates depend on firm size? Small Business Economics, 39, 937-947.

BINET, L. \& FIELD, P. 2013. The long and the short of it: Balancing short and long-term marketing strategies, London, Institute of Practitioners in association with Thinkbox.

BRONNENBERG, B. J., DHAR, S. K. \& DUBÉ, J. P. H. 2011. Endogenous sunk costs and the geographic differences in the market structures of CPG categories. Quantitative Marketing and Economics, 9, 1-23.

BUZZELL, R. D., GALE, B. T. \& SULTAN, R. G. M. 1975. Market Share - A Key to Profitability. Harvard Business Review, 53, 97-106.

DAUNFELDT, S.-O. \& ELERT, N. 2013. When is Gibrat's law a law? Small Business Economics, 41, 133-147. 
DAVCIK, N. S. \& SHARMA, P. 2016. Marketing resources, performance, and competitive advantage: A review and future research directions. Journal of Business Research, 69, $5547-5552$.

DAWES, J., NENYCZ-THIEL, M., GRAHAM, C. \& MCCOLL, B. 2019. Premiumisation strategy as a way to grow. ADMAP. WARC.

DAWES, J. G. 2016. Brand growth in packaged goods markets: Ten cases with common patterns. Journal of Consumer Behaviour, 15, 475-489.

DAY, G. S. 2002. Marketing and the CEO’s Growth Imperative. 1-20.

DEKIMPE, M. G. \& HANSSENS, D. M. 1995. Empirical Generalizations About Market Evolution and Stationarity. Marketing Science, 14, G109-G121.

DEKIMPE, M. G. \& HANSSENS, D. M. 2000. Time-series models in marketing: Past, present and future. International Journal of Research in Marketing, 17, 183-193.

DEKIMPE, M. G., HANSSENS, D. M. \& SILVA-RISSO, J. M. 1998. Long-run effects of price promotions in scanner markets. Journal of Econometrics, 89, 269-291.

EDELING, A. \& HIMME, A. 2018. When does market share matter? New empirical generalizations from a meta-analysis of the market share-performance relationship. Journal of Marketing, 82, 1-24.

EHRENBERG, A. 1994. Theory or Well-Based Results: Which Comes First? In:

LAURENT, G., LILIEN, G. L. \& PRAS, B. (eds.) Research Traditions in Marketing. Boston: Kluwer Academic Publishers.

EHRENBERG, A. \& BOUND, J. A. 1993. Predictability and prediction. Journal of the Royal Statistical Society, 156, 167-206.

ERIKSSON, T., ROBERTSON, J. \& NÄPPÄ, A. 2020. Functional top management teams and marketing organization: exploring strategic decision-making. Journal of Strategic Marketing, 1-18.

EVANS, D. S. 1987. The relationship between firm growth, size, and age: Estimates for 100 manufacturing industries. The Journal of Industrial Economics, 567-581.

FARRIS, P. W., BENDLE, N. T., PFEIFER, P. E. \& REIBSTEIN, D. J. 2010. Marketing metrics: The Definitive Guide to Measuring Marketing Performance, Upper Saddle River, New Jersey, Pearson Education.

FAZZARI, S. M., HUBBARD, R. G., PETERSEN, B. C., BLINDER, A. S. \& POTERBA, J. M. 1988. Financing Constraints and Corporate Investment. Brookings Papers on Economic Activity, 1988, 141-206. 
FRANSES, P. H., SRINIVASAN, S. \& BOSWIJK, P. Testing for unit roots in market shares. Marketing Letters, 2001. Springer, 351-364.

FREEL, M. S. \& ROBSON, P. J. A. 2004. Small Firm Innovation, Growth and Performance:Evidence from Scotland and Northern England. International Small Business Journal, 22, 561-575.

GERMANN, F., EBBES, P. \& GREWAL, R. 2015. The Chief Marketing Officer Matters! Journal of Marketing, 79, 1-22.

GIBRAT, R. 1931. Les inégalités économiques: applications: aux inégalités des richesses, à la concentration des entreprises, aux populations des villes, aux statistiques des familles, etc., d'une loi nouvelle, la loi de l'effect proportionnel, Recueil Sirey.

GORDON, M. J. \& ROSENTHAL, J. S. 2003. Capitalism's growth Imperative. Cambridge Journal of Economics, 27, 25-48.

GRAHAM, C. D. A. 2009. What's the point of Marketing anyway? The prevalence, temporal extent and implications of long-term market share equilibrium. Journal of Marketing Management, 25, 867-874.

GUPTA, P. D., GUHA, S. \& KRISHNASWAMI, S. S. 2013. Firm growth and its determinants. Journal of Innovation and Entrepreneurship, 2, 15.

GUPTA, S., GALLEAR, D., RUDD, J. \& FOROUDI, P. 2020. The impact of brand value on brand competitiveness. Journal of Business Research, 112, 210-222.

HESHMATI, A. 2001. On the Growth of Micro and Small Firms: Evidence from Sweden. Small Business Economics, 17, 213-228.

HYMER, S. \& PASHIGIAN, P. 1962. Firm Size and Rate of Growth. Journal of Political Economy, 70, 556-569.

KENNEDY, R., SCRIVEN, J. \& NENYCZ-THIEL, M. 2014. When 'significant' is not significant. International Journal of Market Research.

KRIZ, A., VOOLA, R. \& YUKSEL, U. 2014. The dynamic capability of ambidexterity in hypercompetition: qualitative insights. Journal of Strategic Marketing, 22, 287-299.

KUMAR, B. R., SUJIT, K. S. \& ABDUL, W. K. 2019. Brand valuation-examining the role of marketing on firm financial performance. Measuring Business Excellence, 24, 90113.

LEE, D. 2013. Nokia: The rise and fall of a mobile giant [Online]. London, United Kingdom: BBC News. Available: https://www.bbc.com/news/technology-23947212 [Accessed 5 March 2020]. 
LEE, J. 2009. Does Size Matter in Firm Performance? Evidence from US Public Firms. International Journal of the Economics of Business, 16, 189-203.

LEEFLANG, P. S. H., WIERINGA, J. E., BIJMOLT, T. H. A. \& PAUWELS, K. H. 2017. Advanced Methods for Modeling Markets, Cham, Switzerland, Springer.

LODISH, L. M. \& MELA, C. F. 2007. If brands are built over years, why are they managed over quarters? Harvard Business Review, 85, 104-112.

LUMPKIN, G. T. \& DESS, G. G. 1996. Clarifying the Entrepreneurial Orientation Construct and Linking It to Performance. The Academy of Management Review, 21, 135-172.

MORGAN, N. A., WHITLER, K. A., FENG, H. \& CHARI, S. 2019. Research in marketing strategy. Journal of the Academy of Marketing Science, 47, 4-29.

MORONE, P. \& TESTA, G. 2008. FIRMS GROWTH, SIZE AND INNOVATION AN INVESTIGATION INTO THE ITALIAN MANUFACTURING SECTOR. Economics of Innovation and New Technology, 17, 311-329.

NENYCZ-THIEL, M., MCCOLL, B., DAWES, J., TRINH, G. \& GRAHAM, C. 2018. Predicting Category Growth from Quarterly Penetration. ANZMAC 2018. Adelaide, Australia

NIJS, V. R., DEKIMPE, M. G., STEENKAMP, J.-B. E. M. \& HANSSENS, D. M. 2001. The category-demand effects of price promotions. Marketing Science, 20, 1 - 22.

PAUWELS, K. \& NESLIN, S. A. 2015. Building with bricks and mortar: The revenue impact of opening physical stores in a multichannel environment. Journal of Retailing, 91, 182-197.

SRINIVASAN, S. \& BASS, F. M. 2000. Cointegration analysis of brand and category sales: Stationarity and long-run equilibrium in market shares. Applied Stochastic Models in Business and Industry, 16, 159-177.

TRINH, G. 2014. Predicting variation in repertoire size with the NBD model. Australasian Marketing Journal, 22, 111-116.

UNCLES, M. D. \& WRIGHT, M. 2004. Editorial: empirical generalisation in marketing. Australasian Marketing Journal, 12, 5-12.

VAN HEERDE, H. J., LEEFLANG, P. S. H. \& WITTINK, D. R. 2000. The Estimation of Pre- and Postpromotion Dips with Store-Level Scanner Data. Journal of Marketing Research, 37, 383-395.

VARADARAJAN, R. 2010. Strategic marketing and marketing strategy: domain, definition, fundamental issues and foundational premises. Journal of the Academy of Marketing Science, 38, 119-140. 
VERHOEF, P. C., KANNAN, P. K. \& INMAN, J. J. 2015. From multi-channel retailing to omni-channel retailing: introduction to the special issue on multi-channel retailing. Journal of Retailing, 91, 174-181.

VIGUERIE, P., SMIT, S. \& BAGHAI, M. 2011. The Granularity of Growth: How to Identify the Sources of Growth and Drive Enduring Company Performance, Wiley.

VON KROGH, G. \& RAISCH, S. 2007. It pays to keep your growth targets realistic. Financial Times, 12/10/2007.

WEERAWARDENA, J., O'CASS, A. \& JULIAN, C. 2006. Does industry matter? Examining the role of industry structure and organizational learning in innovation and brand performance. Journal of Business Research, 59, 37-45.

WILBUR, K. \& FARRIS, P. 2014. Distribution and market share. Journal of Retailing, 90, 154-167.

WILKIE, D. C. \& JOHNSON, L. W. 2017. The existence of double jeopardy within the order of entry effect. Journal of Strategic Marketing, 25, 334-341.

WILLIAMS, S. D. 2007. Gaining and losing market share and returns: a competitive dynamics model. Journal of Strategic Marketing, 15, 139-148.

WINZAR, H., BAUMANN, C. \& CHU, W. 2018. Brand competitiveness: introducing the customer-based brand value (CBBV)-competitiveness chain. International Journal of Contemporary Hospitality Management, 30, 637-660. 
Appendix A: Research Data - Product Categories and Number of Competitive Firms

\begin{tabular}{|c|c|c|c|c|}
\hline $\begin{array}{l}\text { Product Category / } \\
\text { Department }\end{array}$ & No. of Firms & $\begin{array}{c}\text { Avg. Market Size } \\
\text { (Sales in Currency M) }\end{array}$ & $\begin{array}{l}\text { No. of } \\
\text { Years }\end{array}$ & Country \\
\hline Baby Care & 2 & 4895 & 4 & USA \\
\hline Groceries & 5 & 10621 & 3 & USA \\
\hline Groceries & 8 & 1864 & 3 & USA \\
\hline Hair Care & 10 & 6737 & 4 & USA \\
\hline Household Cleaning & 7 & 556 & 3 & USA \\
\hline Household Cleaning & 11 & 466 & 3 & USA \\
\hline Household Cleaning & 2 & 690 & 3 & USA \\
\hline Household Cleaning & 8 & 545 & 3 & USA \\
\hline Household Cleaning & 7 & 230 & 3 & USA \\
\hline Household Cleaning & 3 & 386 & 3 & USA \\
\hline Household Cleaning & 1 & 199 & 3 & USA \\
\hline Household Cleaning & 7 & 131 & 3 & USA \\
\hline Household Cleaning & 2 & 651 & 3 & USA \\
\hline Household Cleaning & 6 & 191 & 3 & USA \\
\hline Household Cleaning & 3 & 247 & 3 & USA \\
\hline Household Cleaning & 3 & 4924 & 4 & USA \\
\hline Household Cleaning & 7 & 536 & 3 & USA \\
\hline Laundry Care & 4 & 290 & 3 & USA \\
\hline Laundry Care & 1 & 23 & 3 & USA \\
\hline Laundry Care & 6 & 273 & 3 & USA \\
\hline Laundry Care & 5 & 2254 & 4 & USA \\
\hline Oral Care & 5 & 472 & 4 & USA \\
\hline Oral Care & 7 & 1422 & 4 & USA \\
\hline Oral Care & 4 & 2996 & 4 & USA \\
\hline Oral Care & 6 & 1598 & 4 & USA \\
\hline Packaging & 1 & 828 & 3 & USA \\
\hline Packaging & 4 & 616 & 3 & USA \\
\hline Packaging & 3 & 1593 & 3 & USA \\
\hline Packaging & 3 & 283 & 3 & USA \\
\hline Personal Hygiene & 3 & 1282 & 4 & USA \\
\hline Personal Hygiene & 4 & 8665 & 4 & USA \\
\hline Personal Hygiene & 6 & 462 & 4 & USA \\
\hline Personal Hygiene & 4 & 2790 & 4 & USA \\
\hline Pest Control & 9 & 670 & 5 & USA \\
\hline Pest Control & 5 & 380 & 5 & USA \\
\hline Pet Care & 3 & 1576 & 5 & UK \\
\hline Pet Care & 3 & 1339 & 5 & UK \\
\hline Pet Care & 2 & 5369 & 5 & UK \\
\hline Skin Care & 9 & 3715 & 4 & USA \\
\hline
\end{tabular}

